\title{
The ethical dimension of digital competence in teacher training
}

\author{
Carlos Novella-García ${ }^{1}$ (1) - Alexis Cloquell-Lozano ${ }^{1}$ (1)
}

Received: 25 November 2020 / Accepted: 3 January 2021/ Published online: 13 January 2021

(C) The Author(s), under exclusive licence to Springer Science+Business Media, LLC part of Springer Nature 2021

\begin{abstract}
Communication technologies should be considered as a means available for people to pursue the objectives of supporting the development of equality, freedom, solidarity and socialisation. In this case, Infant and Primary Education teachers play an important role in the acquisition of digital competences by their students. In this article we ask to what extent the university degrees of Early Childhood and Primary Education Teachers in Spain, where students are trained in subjects related to the use and learning of ICT applied to Education, address digital competences from the ethical dimension. We present here some of the results of a research project carried out in Spain, using the method of content analysis, in which a total of 118 study plans for the 2019-20 university degrees were reviewed. The research results indicated that, although digital competences were present in most of the assessed plans (78\%), through a subject related to the learning and use of ICT in education, only $26.1 \%$ of the teaching guides incorporated the ethical dimension of this subject. This leads us to conclude that future teachers currently receive little training in ethics regarding the development of digital competences.
\end{abstract}

Keywords Teachers · Ethics · Technology $\cdot$ University $\cdot$ Early childhood · Primary education

\section{Introduction}

The use of Information and Communication Technologies (ICT) has spread widely in Spanish homes over the previous decade. According to data from the periodical Survey

Carlos Novella-García

carlos.novella@ucv.es

Alexis Cloquell-Lozano

alex.cloquell@ucv.es

1 Department of General Didactics, Theory of Education and Educational Innovation, Universidad Católica de Valencia San Vicente Mártir, Valencia, Spain 
on Equipment and Use of Information and Communication Technologies in households that was compiled by the National Institute of Statistics (INE) from 2006, the percentage of households with internet access has risen from $57.8 \%$ in the year 2010 to $91.4 \%$ in 2019, and the percentage of homes that have some type of computer has risen from $67.4 \%$ to $80.9 \%$ respectively. This increase is mainly due to the increase in tablets, which are currently present in $56.8 \%$ of households.

Thus, the incursion of ICTs into human activity and the family environment has not gone unnoticed among the so-called "digital natives", who, according to Prensky (2001), were born and raised in an environment where the common use of ICTs has been normalized and therefore they have considered these technologies as something natural to their lives. In fact, computer use has gone from $74.4 \%$ among the population aged $10-15$ years in 2010 to $89.7 \%$ in 2019 , while internet use has increased from $72.2 \%$ to $92.9 \%$ respectively. Another of the devices where use and consumption by the population has significantly increased in recent years is the mobile phone $(58.4 \%$ in 2010 versus $66 \%$ in 2019) (INE).

In this context, ICTs carry with them the parallel development of specific training programs that allow the proper manipulation of the specific technology in its instructional component. When this type of program only bases its objectives on procedural use and does not incorporate the ethical dimension, the probability of making inappropriate or indiscriminate use of the technology increases, which increases, especially among minors, risk situations and dangers through the network, such as are the cases of, for example, flaming, grooming, cyberbullying, phishing, sexting. According to Murcia et al. (2016), the real problem is the absence of responsibility in the use of ICTs, especially by the youngest children who at their age are not yet capable of assessing the risks to which they are exposed.

In this regard, from the analysis of the information extracted from the Crime Statistics System of the Ministry of the Interior, it can be seen how, throughout this last decade, cases of victimization of minors on the network have increased (Fig. 1). In this sense, it should be noted that the behaviour of under-age victims does not follow the same pattern as adult victims. In fact, minors are more vulnerable to other types of criminal acts, specifically threats and coercion, and sexual crimes.

Secondly, the number of arrests and those investigated for crimes committed online in the 14 to 17-year-old age group has also increased throughout this period. Consequently, the total number of arrests made by the Security Forces and Bodies has gone from 189 cases in the year 2011 to 570 in 2019. The vast majority of arrests/ investigations that were carried out in this last year, in this same age group, were related to crimes of a sexual nature (38.9\%) and threats and coercion (23.6\%).

In summary, this should lead us to ask ourselves if ICT use is appropriate and to what degree inappropriate use can lead to the risk or loss of privacy of users due to an absence of ethics in that use. The dangers that can even affect the culture of society due to inappropriate use of ICT can grow exponentially when educational agents, including the school itself or the university, are inactive. If we add to this the new current situation, meaning COVID-19 and the paradigm shift that it has forced on the educational system, the use of ICT has become more essential in the teaching-learning process.

In this process, the work of the teacher is essential to the quality of teaching and learning, but the prescribed curriculum, which as an instrument determines the practice 


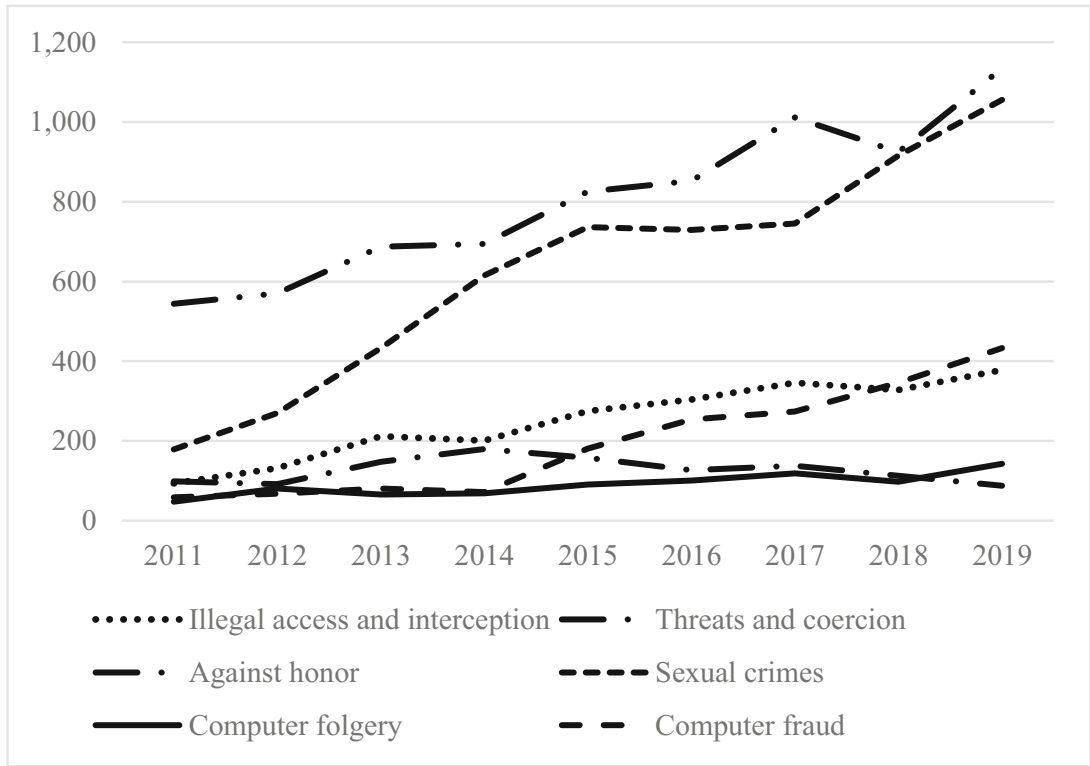

Source: Crime Statistics System. Ministry of the Interior (2019)

Fig. 1 Cases of victimization of minors according to the type of criminal act (2011-2019). Source: Crime Statistics System. Ministry of the Interior (2019)

in the classroom, is no less important (García Rubio \& Ros 2018). Apparently, as Gracia (2018) argued, technical rationality prevails in formal education, which makes students "technically competent" in having proficiency in certain skills, ignoring the fact that this type of rationality can become a serious danger, even for individuals themselves, if it is not based in turn on humanistic principles and values. Hence comes one of the questions posed by Gracia that could be asked by educators. "Is it enough to be technically competent or, based on the values that we think are inalienable, is it also necessary to know how to direct that instrumental knowledge" (Gracia 2018, p. 77).

For these reasons, we want to focus the attention of this article on determining to what extent the university degrees of Infant and Primary Education in Spain, in which students are trained on subjects related to the use of ICT, address the ethical dimension of digital competence. Therefore, we do not perform an analysis of the institutional models of digital teacher competence, but we do address the importance of the ethical dimension in the initial digital training of future teachers. In our understanding, we consider that ethical training in ICT subjects of future teachers, as educational and socializing agents, can contribute to students at both the Infant and Primary educational levels making appropriate use of technologies as well as contributing to the growth and full development of the human personality.

In this context, we want to clarify that the National Agency for Quality Assessment and Accreditation (NAQA, ANECA in spanish language) is the body that regulates university degrees in Spain. It is an autonomous body, attached to the Ministry of Science, Innovation and Universities, which has been created by article 8 of Law 15/ 2014, of September 16, on rationalization of the Public Sector and other administrative reform measures, resulting from the conversion of the National Agency for Quality 
Assessment and Accreditation Foundation into a public body, which aims to contribute to the improvement of the quality of the higher education system by evaluating, certification and accreditation of teachings, teachers and institutions.

The NAQA conducts a review of the study plan every 6 years in order to allow continuing with the homologation (accreditation) or not of the degree offered by the university. In the correction period, non-substantial modifications to the study plan may be included, so the ethical dimension could be incorporated or removed from the ICT subject depending on the approach to the teaching / learning process of the university itself. This approach will then be submitted to ANECA for approval through the VERIFICA (CHECK) program that evaluates the proposals of the degree study plans designed in line with the European Higher Education Area. Once these requirements are met, the degree is considered "accredited". As established in Royal Decree $1393 / 2007$, degrees must renew said accreditation, in general, every 6 years in the case of degrees and every 4 years in the case of University master's degrees.

The data we took as the basis for the preparation of this article came mainly from a research project in which the study plans of Spanish universities, included the Conference of Rectors of Spanish Universities (CRUE) offering Teacher Training Degrees in Infant Education and Primary Education in the 2019-20, academic year were reviewed and analysed. This study was carried out in two phases. A first exploratory stage, in which the Spanish universities offering these courses were identified, and which allowed us to select a total of 61 universities. And a second phase, which consisted of reviewing the 118 degree curricula, in order to identify which have subjects related to digital competence and which of these include the ethical dimension in the training.

\section{The ethical use of ICT in digital citizenship}

The situation forces us to consider the need to intervene in education to safeguard democratic coexistence in our societies, where civic and social responsibility are one of the main references for citizenship. In this sense, civic ethics, understood as the set of moral norms that govern our behaviours and attitudes in favour of the common good, is particularly important.

In the case at hand, the ethical use of ICTs promotes a code of responsible conduct for citizens when using these technologies based on three essential features, namely: a) democratic; which implies accessibility for everyone without the existence of barriers of any kind; b) relevance; that is, responding to the specific and real needs of the digital citizen and c) pertinence; where its use does not entail harming oneself or others (Rodríguez-Porrero and Gil 2014).

ICTs can bring about great social and personal benefits as long as they are developed and used in an ethical framework that guarantees respect for people in all its dimensions. The current social situation indicates that we are in a digital culture where audiovisual communication is pervasive in an excessively media-orientated environment, including computers and social networks, which make communications more convergent by flowing into the same device. These same devices turn users into recipients but also producers of messages (Gozálvez et al. 2014). Along these lines, it can be said that the benefits of Web 2.0 have contributed to this exchange of roles (Jover et al. 2015). 
The forceful incursion of these types of technology makes it even more necessary to establish rules that regulate this relationship without endangering the privacy and dignity of people. Gozálvez (2014) claims, along the same lines, that "civic, dialogic, humanistic and modern ethics must be fully involved in the heart of media culture" ( $p$. 94). The fundamental principle for such good use is to frame this type of technology in an ethical code that does not allow crossing the limits of dignity and human responsibility in its use. This need must be covered from all social areas and, especially, education, both in families and at school. Establishing educational programs that ethically develop technological competences from the first years of schooling will undoubtedly help to strengthen ethics in communication technologies. Olcott Jr. et al. (2015), taking into account Hans Jonas's statements on the principle of human responsibility, claim that responsibility is key to the ethical use of ICTs, referring to personal, formal and legal responsibilities in the framework of moral values and principles as well as from the anticipation and forecast of the effects of their actions and decisions.

The increasingly notorious presence of ICTs in the educational field has been a great challenge for the academic community. It has been forced to consider not only teaching methods and styles but also how to integrate them ethically. These changes are "understood as an element that must satisfy the real, latent and/or patent educational needs of teachers and students, as well as of institutions, so that their curricular integration is a pure and complete reality" (Marín et al. 2012, p. 58). Precisely, in the regulatory framework, the latest Spanish educational laws such as the LOE (2006) and the LOMCE (2013) intensely underline learning and development of digital competences by children, from the standpoints of creative, critical, responsible and safe use. Thus, Royal Decree 1630/2006, of 29 December, which establishes the minimum teaching topics of the second year of Infant Education, establishes that in "audiovisual language and the information and communication technologies present in children's lives require an educational treatment that, based on appropriate use, initiates girls and boys in understanding audiovisual messages and in their appropriate use" (p. 13). Similarly, Order ECD/65/2015, of 21 January, which describes the relationships between competences, content and evaluation criteria of primary education with respect to digital competence, highlights the need to "develop an active, critical and realistic attitude towards technologies and technological media, valuing their strengths and weaknesses and respecting ethical principles in their use" (p. 6996).

In the European Framework, the Digital Education Action Plan ( 2018) raises the need for education and training systems to help achieve better use of innovation and digital technology as well as the development of relevant digital skills. The second priority of this Plan establishes that digital competences are equivalent to the safe and critical use of digital technology, covering the knowledge, skills and attitudes that all citizens need in a rapidly evolving digital society. In this approach, the teaching staff and their initial training are highly relevant for achieving the effectiveness of these objectives.

Likewise, this perspective is recognized both in the OECD TALIS 2018 Results report ( 2019) and in the Eurodyce ( 2019) report Digital Education at School in Europe. Both reports highlight the key role that teachers must play in order to ensure the proper use of ICTs by students. This responsibility implies that the initial university training of teachers must carry with it learning regarding the appropriate, critical, reflective and ethical use of ICTs. In this latest report, Spain appears among the 
European countries with the highest number of regulations or high-level (Ministry) recommendations on the inclusion of specific digital competences in the initial training of teachers of Primary and Secondary Education.

However, the results for Spain in the 2nd Survey of Schools, ICT in Education of the European Union (2019), reveals that Primary Education teachers have high confidence in all areas that correspond to digital competences, except in security and appropriate use of ICTs, where they fall below the European average. Something similar was found with students of the same educational level, whose results on security with ICTs were slightly below the European average, being considered as having low trust in ICTs.

In Spain, Order ECI/3857/ 2007, of 27 December, which establishes the requirements for the verification of official university degrees that enable the exercise of the profession of Teacher in Primary Education, establishes among the competences that students must acquire, competence 11 that refers to knowing and applying ICTs in the classroom, reflecting on their relevance in a way that contributes to learning, civic training (ethics) and cultural wealth. However, Order ECI/3854/ 2007 corresponding to Infant Education and published the same day, points out the importance of promoting initiation in the use of ICT from the framework of respect for human rights.

This framework reveals that ICTs should be learned not only to increase technical proficiency but also to be used in such a way that they lead to the development of human attitudes and values based mainly on respect for ethical principles, such as respectful coexistence, and that they offer the necessary security in use. In short, "promoting and identifying horizons of human fulfilment through technology, promoting the most positive uses and reflecting on negative uses. To critically reflect from a humanistic perspective on the values promoted by technologies" (García 2013, p. 134). The question we must ask ourselves is, to what extent do Spanish university degrees, which prepare students to be teachers, integrate ethical competences in the use of ICTs into their study plans. We will try to answer this question later.

Ethics must become one of the key pieces of education so that it inherently affects all the competences that are intended to be achieved through the various teaching-learning processes. It is here where teachers acquire something of vital importance for their development in the classroom depending on their initial ethical-digital university training. As stated by Olcott Jr. et al. (2015) "permanent decision-making associated with the inclusion and use of digital technologies in education must be accompanied by an ethical questioning that justifies the goodness of the acts that are derived from them." (p. 61). This ethics focused, in this case, on the use of ICTs, is the best instrument to ensure that these technologies do not become destabilizers of the civic and human coexistence of today's societies.

\section{The ethical-digital dimension of the teacher in initial university training}

Although the reason for this article is not to enter into an analysis of all the competences in initial teacher training, we will address digital competences, focusing specifically on its ethical dimension. In the scientific literature, there are many definitions of the concept of competence. The Ministry of Education, Culture and Sports (2015) defines it as the "combination of practical skills, knowledge, motivation, ethical values, 
attitudes, emotions and other social and behavioural components that are mobilized together to achieve effective action" (p. 6986). In our case, we frame competence as the ability that a person develops to combine the knowledge, abilities, skills and attitudes acquired in a specific training process in order to solve a complex situation effectively. Escudero (2008) adds the need to "take into consideration established social and ethical criteria" (p. 8). From these foundations, Ferrari (2013), through a study by the European Commission on digital competence in Europe called DIGCOMP, defined it as the ability of citizens regarding the safe, critical and creative use of ICTs to achieve the objectives related to work, employability, learning, leisure, inclusion and/or participation in society. This will therefore be our conceptual framework regarding digital competence.

The current educational context and its relationship with ICT has been the object of increasing attention in academic and scientific circles, giving rise to a considerable body of papers and research that have tried to give an account of the work of teaching and digital competence (European Commission 2019; UNESCO 2019; Hernandez 2017; INTEF 2017; Tejada Fernández and Pozos Pérez 2016; León and Tapia 2013; Buxarrais and Ovide 2011, Area 2010). Others focus their attention mainly on the reform of initial teacher training regarding digital competence with the aim of adjusting it to the new needs and profiles of the students (Cabero Almenara et al. 2020; Castañeda et al. 2018; Moreno Rodríguez et al. 2018; UNESCO 2017; CózarGutiérrez et al. 2016; Cabero Almenara et al. 2020; Gutiérrez et al. 2010). Similarly, the study of the ethical dimension related to the use of ICT, education and teacher training, occupies an increasingly important place in this theoretical corpus that aims to address the difficulties regarding safe, critical, responsible and reflective use of ICT (Flores-Lueg and Roig-Vila 2017; Murcia et al. 2016; Olcott Jr. et al. 2015; Shin 2015; Rodríguez-Porrero and Gil 2014; Fernández 2008).

When dealing with the subject of communication technologies with adults, it can arouse some controversy but when we deal with children and adolescents it can lead us to think that information and communication technologies are being installed in society as one more element of our own culture and, perhaps, it could result in special vulnerability in their development process if done without ethical and reflective training. Gozálvez (2014) warns that "talking about freedom, autonomy and the development of vital projects is something rhetorical in the absence of a system that guarantees equal opportunities in general, and of course education for good use and good management in the media sphere" (p. 104).

If it is intended to prevent this problem, education can play a crucial role and for this it is necessary to review its objectives, its processes, its contents and its evaluation at different educational levels. The main reason is to mitigate the possible negative effects of the inappropriate use of technologies. Education can guarantee the formation of the critical spirit necessary for the profitable use of the technological environment. In this way, citizens, students, need to understand their own digital age skills, with their strengths and weaknesses, making the school context the appropriate space to learn and to achieve appropriate digital competence (Herrera 2015).

León and Tapia (2013) raise the need to integrate competences in the school curriculum so they can be taught and learned in an integral way including the dimensions of information, communication and ethical-social impact. It is in this latter dimension, which in turn integrates social responsibility, on which we want to focus the 
attention of this article but referring, in this case, to the teacher's initial training in ICT. We understand this initial training as the development of professional skills and teaching knowledge (Montero et al. 2017) necessary for the pedagogical use of ICT.

Teachers, depending on their initial training, may collaborate to a greater or lesser degree in this capacity and attitude for appropriate use of technologies by their students. Educating with these means of communication is to incorporate them properly into the classroom to optimise the teaching-learning process in search of significance for the student and the teacher. The method that perhaps most helps to achieve this is the reflective one, so that students learn to guide their emotions by reflections, the pleasure of the indiscriminate use of technologies in opportunity for analysis and, also, so that the teaching-learning process that follows is more motivating and consistent. In this way, it would be necessary to integrate the competence of being "capable of allowing the technologies and typical research processes in the digital world to permeate each of the phases of this systematic reflective practice" into teachers' initial training (Castañeda et al. 2018, p. 13). Therefore, the university system here assumes an essential role in this training.

The university is a space for higher education where most professionals are trained to assume social responsibilities that improve the present. This close relationship leads us to consider that “today's society and ICT force universities to be active elements in professional development so that the introduction of ICT becomes highly relevant in the future of higher education" (Cabero and Marín 2012, p. 2).

The survey carried out by the CRUE in 2016 and in which $83 \%$ of the universities of the Spanish University System participated, identified a stagnation of objective 5.3 Promote the appropriate, ethical and supportive use of ICT (PDI, PAS and students), and in certain cases found a regression with respect to a previous survey (Gómez 2016). Similarly, the research by Gutiérrez and Serrano (2016) carried out on students of the Bachelor's Degree in Primary Education at the University of Murcia, specifically, those taking the subject "Research and ICT" (6 ECTS credits and basic training in nature), highlighted a significant percentage of students who did not have the basic knowledge in the proper and ethical use of ICT.

Following this premise and taking into account what was previously discussed, we could ask ourselves, what role could the university have in the face of this challenge in the use of communication technologies? We consider that the answer would be very broad if we could find the correct one. Perhaps it is better to start with those people who train future professionals from an early age, i.e. the teachers. If this is the initial approach, then we must assess the training that teachers receive in the corresponding university degrees such as the Degree in Infant Education Teaching and Degree in Primary Education Teaching.

\section{Methodology and analysis of results}

The data were obtained by means of a content analysis of a quantitative type of the curricula of the Teaching Degrees in Infant Education and Primary Education taught by the universities that are part of the CRUE. The observation unit of this analysis was the Teaching Guide of the corresponding course relating to the use of ICT in the teaching field and information on the following variables was obtained from each of these units: 
University degree, type of university, course, type of subject, number of ECTS and ethical dimension in digital competence.

For the purposes of this project, a total of 118 study plans of the 2019-20 year were reviewed, 60 belonging to the Degree of Teaching in Infant Education and 58 to the Degree of Teaching in Primary Education. The results of our study show that the subject related to digital competence was included in the majority of the plans assessed ( $78 \%$ of the plans). Breaking down this data according to the type of grade, there were hardly any significant differences between the two $(78.3 \%$ in Infant and $77.6 \%$ in Primary). Likewise, when including digital competence as a subject in the study plans, it should be noted that we found a wide range of definitions or statements in its presentation, among others we highlight, for example: Information and Communication Technologies applied to Primary Education (Complutense University of Madrid); Communication and Information Technology in Education (University of Cádiz); Educational research methods and ICT applications (University of Córdoba); Research, Innovation and ICT applied to Education (University of Cantabria); Information management and ICT (Ramón Llull University); New technologies applied to Infant Education (University of Vigo), etc.

However, only $26.1 \%$ of all the plans included the ethical dimension of ICT in relation to its use as can be seen in Table 1 . This percentage was higher in Primary (31.1\%) than in Infant $(21.3 \%)$ education. Few study plans met the requirements established in Order ECI/3857/ 2007, regarding Primary Education and Order ECI/ 3854/ 2007 corresponding to Infant Education. Similarly, as with the definition or name of the subject related to digital competence, ethical competence also has multiple definitions: Promote positive and at the same time critical attitudes towards the use of ICT (University of Valencia); Selectively discern audiovisual information that contributes to learning, civic training and cultural wealth (Francisco de Vitoria University, Oviedo University, Malaga University); Promote digital citizenship and responsibility in the use of digital resources (University of Salamanca), etc.

Similarly, it is more evident in the teaching guides of private universities $(30.3 \%)$; it is taught in the fourth year of Bachelor's degree (75\%); and is presented as a compulsory subject $(42.9 \%)$ with an allocation of six ECTS. The fact that the ethical dimension is present in $23.5 \%$ of ICT subjects in an "optional" way, may mean that, although there is an academic offer, there will be students who choose not to take this subject of the study plan and both do not receive such training. However, the chi-square test only confirmed a significant difference in the course variable, so we can really affirm that this variable by itself does discriminate those teaching guides that consider the ethical dimension.

In short, although digital competence is increasingly present and embedded in the study plans of Spanish universities that teach the Degrees of Teaching in Infant and Primary Education, which has demanded a new way of designing teaching-learning processes, few courses on ICT learning include the ethical dimension. The development of a series of skills that lead to the achievement of digital competence is subject to procedural rather than attitudinal content. This has repercussions on the way of learning values by young people and adolescents because using the terminology of RodríguezPorrero and Gil (2014), they not only fail to make appropriate use of ICT, but as indicated Pérez (2016), universal values are put aside by those linked to the social and political context in which they live. 
Table 1 Distribution of the ethical dimension in the ICT subject according to the type of degree, university, course and subject

\begin{tabular}{lcc}
\hline Ethical dimension & Yes (\%) & No (\%) \\
\hline University degree & & \\
Infant & 21.3 & 78.7 \\
Primary & 31.1 & 68.9 \\
University & & \\
Public & 23.7 & 76.3 \\
Private & 30.3 & 69.7 \\
Year* & & \\
First & 28.6 & 71.4 \\
Second & 22.6 & 77.4 \\
Third & & 100 \\
Fourth & 75 & 25 \\
Type of subject & & \\
Basic training & 23.7 & 76.3 \\
Compulsory & 42.9 & 57.1 \\
Elective & 23.5 & 76.5 \\
\hline
\end{tabular}

Note: $* p<0.01$ Source: prepared by the author

\section{Discussion and conclusions}

As we have seen, digital competence is currently implemented in most of the study plans of Spanish universities. However, it does so from a merely instrumental perspective; only $26.1 \%$ of the total teaching guides incorporated the ethical dimension in subjects related to the use and learning of ICT.

The danger of only instrumenting the educational laws and the corresponding subject matter can stifle what education should be promoting: the comprehensive development of the person that specifically implies that internal reflection leads to ethics and morality as an essential part of being human. In fact, "if education ignores this ethical-civic dimension then the democratic life of society will be seriously affected by the evil of social demoralization" (Gracia 2018, p. 229).

It is important, not only to formulate laws but also to educate people through educational systems that enable them to develop ethics and morality from the first years of schooling, complementing this with family education to promote reflection in making future citizens' decisions. This reflection incorporates the comparison between external stimuli and the particular reflection based on human values and universal ethics (Taylor 1992).

The different educational agents must contribute to training that is stimulating and the cultivation of ethical-civic values (Gracia 2018). If this challenge is to be achieved, it is important to know which educators are prepared to assume such responsibility. Teachers have an important influence on students in their classes, therefore, if universities train them in the appropriate and ethical use of ICT, not only in the instrumental 
use, coexistence between people will also be promoted, minimising the emergence of addictive pathologies that directly affect people's self-esteem and dignity.

Educating in values requires coordination and teamwork on the part of the teaching staff, an educational commitment that implies transversality of educational action (transversal competences) and a design applied to a global strategy. This, as Pérez (2016) points out "implies the existence of well-trained teachers, with an open, flexible, innovative and tolerant mentality" (p. 60) capable of facing the challenges currently posed by the information society and of course the educational system. For Manuel Castells, when asked about the role that the school should play in the face of the challenge of new technologies, he does not hesitate to point out that it has a fundamental role in the transmission of values and socialisation through behavioural rules, taking into account that education begins with the education of educators (Pascual 2007). However, the need to link the ethical dimension to digital competence in initial teacher training is even more evident, and for this, Spanish universities must take this first step.

\section{Availability of data and material 'Not applicable'.}

\section{Authors' contributions 'Not applicable'.}

Funding This work was supported by Universidad Católica San Vicente Mártir.

\section{Compliance with ethical standards}

Declarations All manuscripts must contain the following sections under the heading 'Declarations'. If any of the sections are not relevant to your manuscript, please include the heading and write 'Not applicable' for that section.

To be used for non-life science journals.

Conflicts of interest/competing interests 'Not applicable'.

Code availability 'Not applicable'.

\section{References}

Area, M. (2010). El proceso de integración y uso pedagógico de las TIC en los centros educativos. Un estudio de casos. Revista de educación, 352, 77-97.

Buxarrais, M, R., Ovide, E. (2011). El impacto de las nuevas tecnologías en la educación en valores del siglo XXI. Revista Sinéctica, 37. http://www.sinectica.iteso.mx/index. php?cur=37\&art=37_11. Accessed 10 April 2020.

Cabero Almenara, J., Vázquez-Cano, E., López Meneses, E., \& Jaén Martínez, A. (2020). Posibilidades formativas de la tecnología aumentada. Un estudio diacrónico en escena- rios universitarios. Revista Complutense de Educación, 31(2), 143-154.

Cabero, J., \& Marín, V. (2012). ICT training of university teachers in a personal learning environment. Project DIPRO 2.0. Journal New Approaches in Educational Research, 1(1), 2-7. https://doi.org/10.7821/naer.1. 1.2-6.

Castañeda, L., Esteve, F., \& Adell, J. (2018). ¿Por qué es necesario repensar la competencia docente para el mundo digital? Revista de Educación a Distancia, 56, 2-20. https://doi.org/10.6018/red/56/6. 
Cózar-Gutiérrez, R., Moya-Martínez, D., María, V., Hernández-Bravo, J. A., \& Hernández-Bravo, J. R. (2016). Conocimiento y Uso de las Tecnologías de la Información y las Comunicaciones (TIC) según el Estilo de Aprendizaje de los Futuros Maestros. Formación universitaria, 9(6), 105-118.

Escudero, J. M. (2008). Las competencias profesionales y la formación universitaria: posibilidades y riesgos. Revista de Docencia Universitaria, 6(2), 1-20.

European Comission. (2018). Communication from the Commission to the European Parliament, the Council, the European Economic and Social Committee and the Committee of the regions on the Digital Education Action Plan. https://eur-lex.europa.eu/legal-content/EN/TXT/PDF/?uri=CELEX:52018DC0022\&from= ES . Accessed 8 May 2020.

European Commission/EACEA/Eurydice. (2019). Digital education at School in Europe. In Eurydice report. Luxembourg: Publications Office of the European Union.

European Union (2019). 2nd survey of schools: ICT in education. Luxembourg: European Commission. doi: https://doi.org/10.2759/23401. Accessed 8 May 2020.

Fernández, B. (2008). Implicaciones éticas en el uso de las tecnologías de la información y la comunicación en el currículo de formación docente. Revista de Investigación, 65, 171-195.

Ferrari, A. (2013). DIGCOMP: A framework for developing and understanding digital competence in Europe. http://ftp.jrc.es/EURdoc/JRC83167.pdf . Accessed 15 February 2020.

Flores-Lueg, C., \& Roig-Vila, R. (2017). Factores personales de estudiantes de Pedagogía que inciden en su formación social, ética y legal del uso de TIC. Revista Hipótese, 3(3), 3-25.

García, J. (2013). Aproximación ética a la competencia digital. Los niveles de uso y sentido en ámbitos educativos virtuales. TESI, 14(3), 121-145.

García Rubio, J., \& Ros, A. (2018). El currículum básico como referente del derecho a una educación de calidad. Edetania. Estudios y propuestas socioeducativas, 53, 153-167.

Gómez, J. (Ed.). (2016). UNIVERSITIC 2016. Análisis de las TIC en las Universidades Españolas. Madrid: Crue Universidades Españolas.

Gozálvez, V. (2014). Ciudadanía mediática: una mirada educativa. Madrid: Dykinson.

Gozálvez, V., García Ruiz, R., \& Aguaded Gómez, J. (2014). La formación en competencias mediáticas: una cuestión de responsabilidad ética en educación superior. Revista Interuniversitaria de Formación del Profesorado, 79(28.1), 17-28.

Gracia, J. (2018). El desafio ético de la Educación. Madrid: Dykinson.

Gutiérrez, I., \& Serrano, J. L. (2016). Evaluation and development of digital competence in future primary school teachers at the University of Murcia. Journal New Approaches in Educational Research, 5(1), 5359. https://doi.org/10.7821/naer.2016.1.152.

Gutiérrez, A., Palacios, A., y Torrego, L. (2010). La formación de los futuros maestros y la integración de las TIC en la educación: anatomía de un desencuentro. Revista de Educación , 352, 215-231.

Hernandez, R. M. (2017). Impacto de las TIC en la educación: Retos y Perspectivas. Propósitos y Representaciones, 5(1), 325-347. https://doi.org/10.20511/pyr2017.v5n1.149.

Herrera, A. M. (2015). Una mirada reflexiva sobre las TIC en Educación Superior. Revista Electrónica de Investigación Educativa, 17(1), 1-4 http://redie.uabc.mx/voll7no1/contenido-lopezmoya.html. Accessed 8 May 2020.

INTEF (2017). Marco Común de Competencia Digital Docente. Recuperado de: https://aprende.intef.es/sites/ default/files/2018-05/2017_1020_Marco-Común-de-Competencia-Digital-Docente.pdf . Accessed 5 June 2020.

Jover, G., Gónzalez, M. R., \& Fuentes, J. L. (2015). Exploración de nuevas vías de construcción mediática de la ciudadanía en la escuela: de Antígona a la narrativa transmedia. Teoría de la Educación, 27, 69-84.

León, J. \& Tapia, E. (2013). Educación con TIC para la sociedad del conocimiento. Revista Digital Universitaria [en línea], 14 (1). http:/www.revista.unam.mx/vol.14/num2/ art16/\#up . Accessed 5 June 2020.

Marín, V., Vázquez, A., \& Cabero, J. (2012). Redes Sociales Universitarias. El caso de la red DIPRO 2.0. Bordón, 64(4), 49-60.

Montero, L., Martínez, E., \& Colén, M. (2017). Desarrollo del conocimiento profesional en la formación inicial de maestros. Profesorado. Revista de currículum y formación del profesorado, 21(1), 1-16.

Moreno Rodríguez, M. D., Gabarda Méndez, V., \& Rodríguez Martín, A. M. (2018). Alfabetización informacional y competencia digital en estudiantes de magisterio. Profesorado. Revista de currículum y formación del profesorado, 22(3), 253-270.

Murcia, E., Arias, J. L., \& Osorio, S. M. (2016). Software educativo para el buen uso de las TIC. Revista Entre Ciencias e Ingeniería, 19, 114-125.

OECD, (2019. TALIS 2018 results (volume I): Teachers and school leaders as lifelong learners, TALIS. [Online] Available at: https://doi.org/10.1787/1d0bc92a-en .Accessed 8 May 2020. 
Olcott Jr., D., Carrera Farran, X., Gallardo Echenique, E. E., \& González Martínez, J. (2015). Ética y Educación en la era digital: perspectivas globales y estrategias para la transformación local en Cataluña. RUSC. Universities and Knowledge Society Journal, 12(2), 59-72. https://doi.org/10.7238/ rusc.v12i2.2455.

Orden ECI/ 3857/2007 de 27 de diciembre por la que se establecen los requisitos para la verificación de los títulos universitarios oficiales que habiliten para el ejercicio de la profesión de Maestro de Educación Primaria (2007). https://boe.es/boe/dias/2007/12/29/pdfs/A53747-53750.pdf. Accessed 8 May 2020.

Orden ECI/3854/2007 (2007), de 27 de diciembre por la que se establecen los requisitos para la verificación de los títulos universitarios oficiales que habiliten para el ejercicio de la profesión de Maestro de Educación Infantil. https://boe.es/boe/dias/2007/12/29/pdfs/A53735-53738.pdf. Accessed 8 May 2020.

Pascual, M. (2007). In what world we live. Conversations with Manuel castells. Madrid: Alianza Editorial.

Pérez, C. (2016). Educación en valores para la ciudadanía. Estrategias y técnicas de aprendizaje. Bilbao: Desclée.

Prensky, M. (2001). Digital Natives, Digital Immigrants. On the Horizon, 9(5), 1-6.

Rodríguez-Porrero, C. \& Gil, S. (2014). Ética y TIC. Madrid: CEAPAT. Colección 12 retos, 12 meses.

Shin, S. K. (2015). Teaching critical, ethical, and safe use of ICT to teachers. Language Learning \& Technology, 19(1), 181-197.

Taylor, C. (1992). The ethics of authenticity. Harvard: Harvard University Press.

Tejada Fernández, J., \& Pozos Pérez, K. V. (2016). Nuevos escenarios y competencias digitales docentes: hacia la profesionalización docente con TIC. Revista de currículum y formación del profesorado, 22(1), 25-51.

UNESCO (2017). Guideline for Competency-based Teacher Training Reform to Facilitate ICT-Pedagogy Integration.: https://ictcomp.guide . Accessed 17 July 2020.

UNESCO (2019). Marco de competencias de los docentes en materia de TIC. Recuperado de: https://unesdoc. unesco.org/ark:/48223/pf0000371024 . Accessed 17 July 2020.

Publisher's note Springer Nature remains neutral with regard to jurisdictional claims in published maps and institutional affiliations. 